\title{
MANAGEMENT OF RUPTURED CORPUS LUTEUM WITH HEMOPERITONEUM IN EARLY PREGNANCY - A CASE REPORT
}

\author{
Renato Bauman ${ }^{1}$ and Gordana Horvat ${ }^{2}$ \\ ${ }^{1}$ Rotunda IVF, Parnell Square, Dublin, Ireland; \\ ${ }^{2}$ Department of Gynecology and Obstetrics, Sveti Duh University Hospital, Zagreb, Croatia
}

SUMMARY - Rupture of the corpus luteum is a frequent condition in women of reproductive age. Because of abdominal pain accompanied by hemoperitoneum, ruptured corpus luteum can easily be confused with ectopic pregnancy. The management of ruptured corpus luteum depends on the symptoms and laboratory findings, and can be just observation but laparoscopy or urgent laparotomy may also be needed. Although rare, hemoperitoneum following rupture of corpus luteum in early pregnancy should always be considered in the diagnostic process. We present a patient that was admitted to our department with amenorrhea, positive 3 hCG and acute abdomen. Emergency laparoscopy was performed but no ectopic pregnancy was found, just blood, coagula and a ruptured corpus luteum. The day after the surgery, intrauterine pregnancy was found on ultrasound and the pregnancy ended with term delivery.

Key words: Pregnancy; Corpus luteum; Hemoperitoneum; Laparoscopy; Abdominal pain; Pregnancy, ectopic

\section{Introduction}

Rupture of the corpus luteum is a frequent condition in women of reproductive age. It is accompanied by acute or chronic pain of variable intensity and intraabdominal blood loss of variable amount, from a few cubic centimeters to massive hemoperitoneum. Therefore, clinical presentation can vary from a benign asymptomatic state to circulatory collapse, even death. Rupture of the corpus luteum can occur over the entire span of a woman's reproductive age ${ }^{1}$, but more commonly in younger women between the age of 16 and $30^{2,3}$. Because of abdominal pain accompanied by hemoperitoneum, ruptured corpus luteum can easily be confused with ectopic pregnancy, especially when rupture occurs in corpus luteum supporting intrauterine

Correspondence to: Renato Bauman, $M D, P h D$, Rotunda IVF, Parnell Square, Dublin, Ireland

E-mail: renato.bauman@rotundaivf.ie

Received September 14, 2015, accepted August 27, 2016 pregnancy. The coincidence of ruptured corpus luteum with ectopic or heterotopic pregnancy has also been reported ${ }^{2-4}$.

Standard management of ruptured corpus luteum is not defined. In a hemodynamically stable patient, without severe abdominal pain and in the presence of only a small amount of pelvic fluid found on ultrasound, observation is a sufficient treatment. In the presence of severe abdominal pain or a large amount of pelvic fluid, laparoscopy should be performed on admission ${ }^{2}$. In hemodynamically stable patients, laparoscopy is considered superior to laparotomy both for diagnosis and treatment ${ }^{5}$, having significant advantages including shorter operating time, improved wound care, less postoperative pain and shorter hospital stay, without increased adverse events. Direct laparotomy is mandatory in the situation of circulatory collapse $^{2}$. Laparoscopic procedures performed during the first trimester of pregnancy, including those performed on adnexa, are accompanied by a low rate of pregnancy loss 6 . 


\section{Case Report}

A 33-year-old woman (para 1, abortion 0) was admitted to general surgery emergency room at 10 p.m. with lower abdominal pain of sudden onset approximately 4 hours prior to admission. Last menstrual period was 34 days before (menstrual cycle 35-40/7). She had no vaginal bleeding, nausea or vomiting, and had regular stool. She complained of painful miction. Physical examination was unsuspecting, revealing elastic, painless abdominal wall, with no guarding or rebound, and regular peristalsis. Laboratory findings: leukocytes $14.07 \times 10^{9} / \mathrm{L}$, red blood cells $4.34 \times 10^{12} / \mathrm{L}$, hemoglobin $132 \mathrm{~g} / \mathrm{L}$, hematocrit 0.391 , C-reactive protein 3.9; proteins (1+), hemoglobin (1+) and leukocytes (1+) were present in urine; urine sediment showed 5-10 red blood cells, 4-6 leukocytes and lots of bacteria; ß-human chorionic gonadotropin (ßhCG) was $510.2 \mathrm{IU} / \mathrm{L}$. In conclusion, no acute surgical condition was found, presumptive diagnosis of urinary infection was made, and urinoculture was suggested. Examination by gynecologist was also suggested.

The patient came to department of gynecology next morning at 10:30 a.m. Now she was amenorrheic for 5 weeks ( 35 days). The pain was now more intense, with aggravation in inspirium, and radiating to both shoulders. There was no vaginal bleeding. She was hemodynamically stable, blood pressure 105/70 mm Hg and pulse $75 / \mathrm{min}$.

Genital finding: per speculam mucus discharge was present in vagina, with no traces of blood, cervix was cillindrically shaped, external cervical os closed. Cervix was painful on palpation and motion, uterus anteflexed, small, right adnexa unsuspecting, tender left adnexa. Abdominal examination was unsuspecting.

Transvaginal ultrasound showed hyperechogenic endometrium, $12 \mathrm{~mm}$ wide, with no gestational sac. A large amount of fluid was seen in the pouch of Douglas. Right ovary was unsuspecting. Corpus luteum was seen in the left ovary, which was surrounded by inhomogeneous echoes of coagula. Adjacent to the ovary was an undefined structure that was suspected of ectopic pregnancy.

Blood count: red blood cells $3.97 \times 10^{12} / \mathrm{L}$, hemoglobin $123 \mathrm{~g} / \mathrm{L}$, hematocrit 0.370 ; coagulation values were normal.

Urgent diagnostic laparoscopy in endotracheal general anesthesia was performed. Pelvis was filled with liquid blood and coagula, which were evacuated,
$700 \mathrm{~mL}$ in total. Uterus and right adnexa were unsuspecting. One paraovarian cyst was found on the left, and one small cyst in the left fallopian tube. Both cysts were extirpated and sent for histopathologic analysis, along with the coagula. Left ovary was covered with attached coagula that were gently removed and also sent for histopathologic analysis. No other source of active bleeding in the abdomen and no signs of ectopic pregnancy were found. Abdominal drain was placed in the pelvis. Since it was a wanted pregnancy, curettage was not performed.

Postoperative recovery was uneventful. The patient felt well after laparoscopy. Abdominal drain was removed on postoperative day 2 .

Histopathologic analysis showed no chorionic villi within evacuated coagula, but there was a cyst of $7 \mathrm{~mm}$ in diameter, with thin fibrous wall lined with tubal epithelium; a sample of tissue of $1 \mathrm{~cm}$ in diameter histologically corresponded to tubal fimbria.

Since there was no intraoperative or histologic evidence for ectopic pregnancy, definitive diagnosis of corpus rubrum hemorrhagicum was made.

The level of ßhCG determined on postoperative day 1 was 762 IU/L. Further rise of hCG was seen on postoperative day 2, with 3 hCG measuring 2190 IU/L. Transvaginal ultrasound revealed an intrauterine gestational sac of $4 \mathrm{~mm}$ in diameter. Within the left ovary, corpus luteum of $3 \mathrm{~cm}$ in diameter was present, and no pelvic fluid was seen.

Follow up blood count obtained on postoperative day 4 was within the expected values (red blood cells $3.68 \times 10^{12} / \mathrm{L}$, hemoglobin $114 \mathrm{~g} / \mathrm{L}$, hematocrit 0.343 ). The patient was discharged on postoperative day 4 and suggested therapy with progesterone vaginal capsules a $100 \mathrm{mg} 3 \times 2$, which she continued until the $10^{\text {th }}$ week of pregnancy.

She had an uneventful pregnancy and spontaneous vaginal delivery at 41 weeks, giving birth to a female child, $5230 \mathrm{~g} / 56 \mathrm{~cm}$, Apgar scores of 10 at $1 \mathrm{~min}$ and 10 at $5 \mathrm{~min}$. During the $2^{\text {nd }}$ and $3^{\text {rd }}$ trimester, she underwent testing for possible diabetes but the glucose tolerance test was normal. Both the mother and the child enjoy good health.

\section{Discussion}

There are few reports of ruptured corpus luteum in pregnancy with hemoperitoneum requiring emergen- 
cy treatment. Vidaković et al. have reported a similar case of a 35-year-old patient admitted to the hospital because of severe abdominal pain with positive 3 hCG and no intrauterine gestational sac visualized on ultrasonography. Laparoscopy was performed and ruptured luteal cyst was found and removed. Postoperatively, normal intrauterine gestation was visualized ${ }^{7}$. Takeda et al. have reported on a 15-year-old girl that was vitally at risk because of intra-abdominal bleeding. Transvaginal ultrasound showed intrauterine gestation but also fluid in the abdomen and heterotopic pregnancy or rupture of corpus luteum of pregnancy was presumed. Laparoscopy revealed bleeding from the corpus luteum cyst and hemostasis was achieved. Blood retrieved from the abdominal cavity was used for autologous transfusion. The intrauterine pregnancy was electively terminated because the pregnancy was not desired ${ }^{8}$.

The patient reported here presented with abdominal pain of sudden onset, positive BhCG and a large amount of fluid in the pouch of Douglas and no visible intrauterine gestational sac found on transvaginal ultrasound examination, which supported a presumptive diagnosis of ruptured ectopic pregnancy. Diagnostic laparoscopy was performed, and no ectopic pregnancy or active bleeding was found. Postoperative laboratory findings showed a rise of $ß \mathrm{hCG}$, and vaginal ultrasound scan showed an intrauterine gestational sac. Further course of pregnancy was uneventful, and she gave birth to a healthy girl at 41 weeks.

Acute pain with evidence of fluid in the abdomen in patients of reproductive age is always suspicious of ruptured ectopic pregnancy. Positive $\mathrm{BhCG}$ is mandatory for the diagnosis following operative therapy. When $\mathrm{BhCG}$ is negative, a more conservative approach is possible if the patient is hemodynamically stable. Historically, explorative laparotomy was performed in similar situations but in the last two decades, laparoscopy has become the appropriate procedure for resolving the majority of gynecologic emergencies.
In conclusion, although extremely rare, rupture of corpus luteum in early pregnancy with hemoperitoneum can cause acute abdomen that mimics rupture of ectopic pregnancy. Diagnostic process involves ultrasound examination and serial BhCG measurements. However, because of acute symptoms, therapy is mainly surgical exploration of the abdomen. Laparoscopy is the gold standard, if possible. Although rare, hemoperitoneum following rupture of corpus luteum in early pregnancy should always be considered in the diagnostic process.

\section{References}

1. Hallat JG, Steele CH Jr, Snyder M. Ruptured corpus luteum with hemoperitoneum: a study of 173 surgical cases. Am J Obstet Gynecol. 1984;149:5-9.

2. Raziel A, Ron-E1 R, Pansky M, Arieli S, Bukovsky I, Caspi E. Current management of ruptured corpus luteum. Eur J Obstet Gynecol Reprod Biol. 1993;50:77-81.

3. Hibbard LT. Corpus luteum surgery. Am J Obstet Gynecol. 1979;135:666-70.

4. Schonberg LA. Combined pregnancy and corpus luteum cyst. Am J Obstet Gynecol. 1979;133:106-7.

5. Teng SW, Tseng JY, Chang CK, Li CT, Chen YJ, Wang PH. Comparison of laparoscopy and laparotomy in managing hemodynamically stable patients with ruptured corpus luteum with hemoperitoneum, J Am Assoc Gynecol Laparosc. 2003; 10:474-7.

6. Schwartzenberg BS, Conyers JA, Moore JA. First trimester of pregnancy laparoscopic procedures. Surg Endosc. 1997;11: 1216-7.

7. Vidaković S, Dokić M, Vilendečić Z, Maravić MD. Ruptured corpus luteum cyst in early pregnancy: a case report. Srp Arh Celok Lek. 2013 Sep-Oct;141(9-10):689-92.

8. Takeda A, Sakai K, Mitsui T, Nakamura H. Management of ruptured corpus luteum cyst of pregnancy occurring in a 15 -year-old girl by laparoscopic surgery with intraoperative autologous blood transfusion. J Pediatr Adolesc Gynecol. 2007 Apr;20(2):97-100.

9. Sun WC, Li W, Chen QH, Tong JY. Corpus luteum hemorrhage in a patient with aplastic anemia. J Obstet Gynaecol Res. 2013 Jan;39(1):399-401. 


\section{Sažetak}

\section{HEMOPERITONEUM U RANOJ TRUDNOĆI UZROKOVAN KRVARENJEM IZ ŽUTOG TIJELA - PRIKAZ SLUČAJA}

\section{R. Bauman i G. Horvat}

Krvarenje iz žutog tijela je česta pojava u žena reprodukcijske dobi. Zbog bolova u trbuhu praćenih hemoperitoneumom krvarenje iz žutog tijela ima sličnu kliničku sliku kao ektopična trudnoća. Postupak kod krvarenja iz žutog tijela ovisi o simptomima i laboratorijskim nalazima i može se sastojati samo od opservacije pacijentice, ali može zahtijevati i dijagnostičku laparoskopiju ili hitnu eksplorativnu laparotomiju. Hemperitoneum zbog krvarećeg žutog tijela u trudnoći je iznimno rijedak. U radu prikazujemo pacijenticu koja je primljena na naš odjel s amenorejom, pozitivnim ßhCG-om i znacima akutnog abdomena. Učinjena je hitna laparoskopija prilikom koje nije nađena ektopična trudnoća, nego krv, ugrušci i krvareće žuto tijelo. Dan nakon laparoskopije je ultrazvučno nađena intrauterina trudnoća koja je završila porođajem zdravog djeteta u terminu.

Ključne riječi: Trudnoća; Corpus luteum; Hemoperitoneum; Laparoskopija; Abdominalna bol; Trudnoća, izvanmaternična 